\title{
GIVING SHAREHOLDERS POWER TO VETO CORPORATE DECISIONS: USE OF SPECIAL CHARTER AND BY-LAW PROVISIONS*
}

\author{
F. Hodge O’Neal $\dagger$
}

This paper examines the planning and drafting problems involved in the use of special charter and by-law provisions to give minority shareholders power to veto corporate decisions. It considers not so much the phrasing of veto provisions for use in the charter and by-laws as the approaches that may be taken to confer a veto. Statutory materials and corporate concepts which determine the validity and efficacy of veto provisions are discussed in considerable detail. Attention is also given to precautions that increase the usefulness of veto provisions or lessen their vulnerability to circumvention or attack.

\section{I}

\section{Faiture of Law and Lawyers to Meet Bustness Need for Veto}

Businessmen forming a closely held corporation not uncommonly consider themselves partners as to each other; they incorporate to obtain limited liability or other corporate advantage. Those who are to have minority interests in the business therefore not infrequently seek protection against the broad powers normally vested in shareholders and directors to determine corporate policy and to make decisions by simple majority vote. ${ }^{1}$ In short, they want a power to veto some or all corporate policies and decisions.

The business situation may call only for a power to veto a particular change in

-This paper was originally prepared in partial fulfillment of graduate writing requirements at the Harvard Law School.

† A.B. I938, IL.B. I940, Louisiana State University; J.S.D. I949, Yale. Dean and Professor of Law, Walter F. George School of Law, Mercer University. Author (with Kurt F. Pantzer) of THE Drafting of Corporate Charters and By-Laws (I95I).

${ }^{1}$ Participants in a closely held corporation often seek to escape other normal attributes of the corporate form of business and to gain for their enterprises advantageous partnership attributes. Typically, they want to restrict the transferability of shares in the corporation and to establish options for the purchase of shares of deceased holders. See Note, 2 A. L. R. 2d 745 (I948). They commonly seek to impose sharp restrictions on the normal authority of the board of directors. They sometimes want profits or voting power allocated on a basis divergent from shareholding. See Nickolopoulos v. Sarantis, I02 N. J. Eq. 585, I4I Atl. 792 (Ct. Err. \& App. 1928). The satisfaction of these desires taxes the ingenuity of lawyers charged with drafting charters, by-laws, and shareholders' agreements for closely held enterprises. Further, the giving of veto powers to shareholders increases the chance of deadlocks and creates a need for a speedy means (perhaps arbitration) of resolving differences, or for a satisfactory method of dissolving the enterprise when corporate paralysis ensues. See Israels, The Sacred Cow of Corporate Existence: Problems of Deadlock and Dissolution, I9 U. of CH. L. Rev. 778 (1952). The authorities considered in this paper and the approaches suggested here for tailoring the corporate form to the shareholders' desire for a veto will often be found pertinent to the other problems that lawyers encounter in drafting corporate instruments. 
the corporate structure. For instance, a participant may be willing to invest in a particular kind of business and in nothing else, and thus he may want to be able to veto charter amendments that would authorize the corporation to engage in other activities. More frequently, business considerations call for a veto over policy decisions, or even over day-to-day decisions on the operation of the enterprise. ${ }^{2}$ In some instances, participants insist on power to veto substantially all corporate acts. ${ }^{8}$

Participants in a closely held enterprise usually expect to become directors and to occupy executive positions. Therefore, they are likely to be especially interested in being able to prevent removal of directors and officers, modification of their authority or duties, and change in their salaries or perhaps in the ratio between salaries. Each shareholder normally wants to be in a position at least to avert salary reduction in the office which he is to hold. On the other hand, a shareholder who puts up the lion's share of the money for an enterprise may well want a veto over salary increases, dividend payments, the purchase or retirement of the corporation's stock, the creation of indebtedness, ${ }^{4}$ and perhaps the issuance of preferred stock.

The difficulty of disposing of holdings in a closely held corporation augments the desire of minority shareholders for a veto over corporate decisions. Restrictions are often placed on the transferability of shares in a closely held corporation; ${ }^{5}$ and, even in the absence of restrictions, a minority interest in a closely held corporation does not have a ready market. The fact that minority shareholders cannot readily withdraw their funds from the venture whenever they become dissatisfied with its operation naturally strengthens their desire for a power to veto corporate decisions.

The business considerations giving rise to the desire for a veto usually have not been reflected in the incorporation papers and other instruments that lawyers have prepared for closely held enterprises. The explanation of this failure to meet business needs lies in part in an absence of legislative recognition of the special management problems of closely held corporations and in part in an inability of lawyers to break away from traditional thinking on corporate management patterns. Statutes and judicial decisions, with but few exceptions, lay down the same rules for all corporations and make no distinction between closely held and widely held enterprises. ${ }^{\circ}$ At the same time, many lawyers have failed to take advantage even of the limited flexibility permitted by existing laws. As they say, they are opposed to giving share-

\footnotetext{
2Sec Bator v. United Sausage Co., 138 Conn. 18, 81 A. 2d 442, 443 (I95I).

${ }^{3}$ Sec McQuade v. Stoneham, 263 N. Y. 323, I89 N. E. 234 (1934) (the amount of capital, the by-laws, the number of shares, salaries, and business policies were to be changed only by unanimous consent); Kaplan v. Block, I83 Va. 327, 3I S. E. 2d 893 (1944) (unanimity required for "any matter concerning the administration and management of the affairs of the corporation").

"See Hart v. Bell, 222 Minn. 69, 23 N. W. 2d 375 (1946) (agreement among sharcholders that dividends would not be declared until loans by a shareholder to the corporation had been paid.)

${ }^{5}$ Participants in a closely held corporation usually want to be able to prevent the admission into the enterprise of new members they consider undesirable. That power can be effectively granted by restrictions on the transfer of stock. See O'Neal, Restrictions on Transfer of Stock in Closely Held Corporations: Planning and Drafting, 65 HaRv. L. REv. 773 (1952). Lawyers throughout the country are familiar with these restrictions, and they are widely used.

- Weiner, Legislative Recognition of the Close Corporations, 27 MrCH. L. Rev. 273 (1929); Wincr, Proposing a New York "Close Corporation Law," 28 ConNell L. Q. (1943).
} 
holders a power to veto corporate decisions or to "tampering in any way" with the customary powers of shareholders and directors to rule by majority vote. The result has been that the management pattern prevalent in widely held corporations has been fastened upon closely held companies.

II

\section{Appronches That May Be Used to Provide a Veto}

\section{A. Available Devices}

If there is a business need for a veto and the lawyer does not look into possible methods of providing it, he is not adequately serving his client. In most jurisdictions, an effective veto can be provided. This paper examines two of the rather numerous devices that are available for use: ${ }^{7}$ namely, (I) charter and by-law provisions requiring unanimity or concurrence of a high percentage of voting units for shareholder or director action; and (2) charter and by-law provisions fixing high attendance requirements for quorums at meetings of shareholders and directors. In many situations, charter and by-law provisions of these two types offer the easiest and most effective means of providing a veto. Other veto devices will be discussed in this paper only in so far as they are serviceable in strengthening or supporting these two methods of achieving a veto.

\section{B. The Business Situation and Statutory Requirements}

Before drafting veto provisions, the lawyer must carefully study the veto problem in relation to the particular business situation with which he is working. He must consider the nature and scope of the enterprise, the number of persons who are to participate in it, the contributions in money, credit, or services that each participant is to make, the personalities and business skills of the participants, the number and identity of persons who are to have veto powers, the activities to which the veto is to apply, and, of course, the preferences of the participants.

Veto provisions require original composition. Clauses in standard forms can at most serve only as "idea guides." In the first place, standard forms usually are prepared with widely held corporations in mind, most often with the aim of giving directors and management as much power and freedom from shareholder control as possible. That aim is of course directly opposed to the objective sought by veto provisions. ${ }^{9}$ Secondly, each participant in a closely held enterprise usually has his own ideas on what his relation to the business should be; and therefore each provision on management must be individual.

${ }^{7}$ Devices and arrangements not discussed in this paper which may be found serviceable in establishing a veto are: $(x)$ classification of shares into voting and non-voting stock, with voting shares distributed in a way to give a balance of voting power and thus a veto, (2) classification of directors, (3) voting agreements and other shareholder agreements, (4) voting trusts, and (5) irrevocable proxies. (195I).

${ }^{8}$ Sec Pantzer and O'Neal, The Drafting of Corporate Charters and By-Laws $\$ \$ 2.03-.04$

The use of forms in drafting the charter and by-laws also raises the danger that provisions inconsistent with the veto clauses will inadvertently be inserted in other parts of the charter or by-laws. See Kear v. Levinson, 7x D. \& C. 475 (Pa. Com. Pl. I950), where a by-law provision was held to have superseded a promoters' agreement entered into before incorporation. 
The lawyer must of course carefully study the corporation statutes of the jurisdiction in which the enterprise is to be incorporated. Those statutes determine the legality of shareholder veto, the activities that may be subjected to veto, the instruments in which the veto provisions must be placed to be effective, and the approach that must be taken (and sometimes the phraseology that must be used) to provide the veto. Typical statutory provisions affecting the legality and efficacy of veto provisions are discussed in another section of this paper. ${ }^{10}$ In some instances, in order to provide an effective veto, the lawyer will have to incorporate the enterprise in a state other than the one in which it is to conduct its principal business.

\section{Division of Decision-Making Power Among Shareholders, Directors, and Officers}

As has been mentioned, participants in a closely held enterprise may want power to veto fundamental corporate changes, important business policies, decisions in the day-to-day operation of the business, or all of these. A requirement of unanimity or of an unsually high vote for shareholder action, for director action, or for both will usually be sufficient to give the veto desired. Occasionally, a high requirement for shareholder or director action must be used in combination with other charter or by-law provisions to achieve a desired veto.

In most jurisdictions, a veto over fundamental changes in the corporate structure can easily be accomplished. Modern corporation statutes provide for shareholder participation in fundamental corporate acts such as charter amendment, merger, consolidation, dissolution, and sale of all assets. A charter provision requiring unanimity for all shareholder action or for those particular acts (assuming that it is properly protected against amendment) will give each shareholder an effective veto over fundamental corporate changes. Similarly, a provision requiring approval of holders of a high percentage of the shares for shareholder action can be used to provide a veto over fundamental acts. For instance, a requirement of approval of holders of 75 per cent of the shares obviously empowers a person holding 30 per cent of the shares to prevent shareholder action-that is, if the requirement is protected against circumvention through the issuance of additional stock. ${ }^{11}$

A high vote requirement for shareholder action can also be used in some instances to protect a shareholder against corporate acts other than major changes in the corporate structure. Here is a simple illustration of how a high vote requirement can be used in combination with other charter provisions to meet a business need for a veto over certain corporate acts. Assume that a corporation is being organized under Missouri law to take over several existing businesses. The most important of the businesses belongs to Black, who is to receive 35 per cent of the corporation's total authorized shares. Black wants protection against dilution of his interest in the corporation by the subsequent issuance of no-par shares to other persons transferring properties to the corporation in exchange for shares. One method of afford-

\footnotetext{
${ }^{10}$ See infra page 457.

${ }^{11}$ See infra page 470 .
} 
ing protection is through appropriate provisions in the articles of incorporation ( $\mathrm{r}$ ) reserving to shareholders the right to fix the consideration to be received for shares without par value, (2) requiring approval of holders of 75 per cent of the outstanding shares for shareholder action fixing the consideration to be received for shares without par value, and (3) requiring a 75 per cent vote for amendment of the articles of incorporation. As the corporation under this arrangement cannot issue additional no-par stock over the dissenting vote of Black's shares, Black (although a minority shareholder) is protected against dilution of the value of his holdings. ${ }^{12}$

High voting requirements for shareholder action, however, usually do not give the power to veto important policy matters such as changes in officers' salaries, or the day-to-day conduct of business. To provide a veto over those kinds of decisions, unanimity or a high vote must be required for director action, and the shareholders for whom a veto is sought must be assured representation on the board of directors. Further, it may be necessary to define narrowly in the charter or the by-laws the authority and duties of corporate officers; otherwise corporate officers may be given authority to perform without director approval acts against which a veto is desired.

Whenever a shareholder has sufficient voting strength to keep a representative on the board, a requirement of unanimity for board action of course gives that shareholder the effective power to veto action within the province of the board. Representation on the board can usually be assured a minority shareholder by the use of cumulative voting or by classifying the shares and providing for election of some directors by one class of shares and other directors by a second class of shares. Another possible method of assuring that a shareholder will have representation on the board is to name the original board in the charter and to require unanimous approval of the shareholders for the election of new board members. This arrangement results in holding over the directors in office if shareholders cannot agree on a new board. Statutes, charters or by-laws not uncommonly provide that directors are to serve until their successors are elected. In some jurisdictions, however, an arrangement of this sort may be invalid. ${ }^{13}$

Whenever a shareholder cannot be assured representation on the board or whenever for any reason an effective veto of board action cannot be given, ${ }^{14}$ a veto of matters ordinarily within the province of the board can sometimes be provided by transferring decision-making power over those matters from the directors to the shareholders ${ }^{15}$ and then requiring unanimity or a high vote for shareholder action.

\footnotetext{
12 This illustration is based on one given in an address by Robert B. Fizzell, of the Kansas City, Missouri, Bar, before the Lawyers Association of Kansas City, April 26, I949.

${ }^{13}$ See Israels and Gorman, Corporate Practice 22 (r953).

"In some jurisdictions, charter and by-law provisions requiring a high vote for director action are somcwhat less likely to be sustained than are similar requirements for shareholder action; statutory authority supporting high requirements for director action is not as abundant and sometimes it is not as free from ambiguity as that supporting high requirements for shareholder action. Compare the statutory materials discussed in Section III(A)(2) of this paper infra page 458, with those discussed in Section III(A)(3) infra page 459.

${ }^{15}$ But see the admonition in Israels and Gorman, Corporate Practice 23 (I953), against vesting power of control in places different from those contemplated by statute.
} 
In Iowa, for example, power to make all corporate decisions apparently can be vested in the shareholders, for the corporation statute of that state does not require a board of directors. ${ }^{16}$ In most states, however, the blanket transfer of all corporate power to the shareholders (completely eliminating the customary functions of the board of directors) probably would not be sustained. In the first place, the great majority of corporation statutes contain sections that vest in the board of directors the management of the corporation and the control of ordinary corporate affairs. ${ }^{17}$ Further, some statutes contain provisions conferring on the board the power to perform specified acts, e.g., the selection of corporate officers. ${ }^{18}$ In some jurisdictions, the control vested in the directors by these statutes apparently cannot be either transferred to the shareholders or limited by a requirement that the shareholders must ratify action taken by the directors before it will be operative. ${ }^{19}$

On the other hand, under many corporation statutes the charter or by-laws may determine whether certain corporate acts are to be performed by the shareholders or by the directors. The Pennsylvania statute, for instance, states that "unless the articles or by-laws provide otherwise, the board of directors shall elect and fix the compensation" of officers and assistant officers. ${ }^{20}$ Thus, if the shareholders want a veto over the selection of corporate officers and the fixing of their salaries, a clause can be inserted in the charter providing that the shareholders shall elect the officers and fix their salaries and that this action can be taken only by a unanimous vote or by a specified vote greater than a majority. Similarly, under the laws of a number

${ }^{10}$ Sec Ballard, Arrangements for Participation in Corporate Management under the Pennsyluania Business Corporation Law, 25 TeMr. L. Q. 131, 132 (1951), citing IowA CODE $\$ \$ 491.2,491.3(7), 491.5$ (1950). ". . . other than as a matter of convenience and policy nothing in the nature of the corporation requires having a board of directors or committing to such a board the management of corporate affairs. . . " Ballard, supra, at 132 .

${ }^{17}$ E.g., Ill. Ann. Stat. c. 32, \$157.33 (1935); Ind. ANN. Stat. \$25-208 (Burns, 1933); PA. Bus. Conp. L. tit. I5, $\$ 2852-40 \mathrm{I}$ (I95I). Section 33 of the Model Business Corporation Act provides that the "business and affairs of a corporation shall be managed by a board of directors." Section $3 \mathrm{I}$ (I) of the Uniform Business "Corporation Act vests control in the directors in even stronger terms; that section states: "The business of every corporation shall be managed by a board of at least three directors. . ." (italics supplied). But see Section $3 I$ (III) of the Uniform Act. On the other hand, DeL. Rev. CODE \$204I (1935) appears to provide for flexibility by stating: "The business of cvery corporation . . . shall be managed by a Board of Directors, except as hereinafter or in its Ccrtificate of Incorporation otherwise provided."

${ }^{18}$ See LA. GeN. CoRp. L. $\$ 35$ (1938) (the board "shall elect a president, a secretary and a treasurer").

${ }^{10}$ See Security Savings \& Trust Co. v. Coos Bay Lumber \& Coal Co., 219 Wis. 647, 263 N. W. 187 (1935), declaring invalid a by-law that required shareholder consent only for specified acts within the province of the directors, namely, the payment of officers and employees. Cf. Warren v. 536 Broad Street Corp., 4 N. J. Super. 584, 68 A. 2d 175 (r949), aff'd, 6 N. J. Super. 170, 70 A. 2d 782 (1950), where the court held that a clause in the charter calling for approval of 75 per cent of the shares before corporate real estate could be leased was subject to amendment but intimated that the clause was valid.

${ }^{20}$ PA. Bus. Corp. L. $\$ 406$ (I95I). See also PA. Bus. Corp. L. tit. 15, art. VI, \$2852-601 (195I), which states: "Unless the articles or by-laws otherwise provide, the board of directors shall have the power, by resolution duly adopted, to issue from time to time, in whole or in part, the kinds or classes of shares authorized in the articles." Under this provision, the articles or by-laws apparcntly could provide either that the shareholders will have the exclusive right to issue stock or that approval of both directors and shareholders will be necessary. Note that in the illustrative problem discussed supra page 454 the first step toward a solution was placing in the charter a provision reserving to the sharcholders the right to fix the compensation to be received for shares without par value. 
of states the charter may require shareholder consent for the execution of corporate mortgages. ${ }^{21}$

III

\section{Statutes Supporting High Vote Requirements}

A. Statutes Authorizing Provisions in the Charter

I. Statutes Applicable to Both Shareholder and Director Action. Most corporation statutes authorize in broad terms the inclusion in the charter of special or optional provisions regulating the conduct of corporate affairs. A number of these statutes list the required contents of the charter and simply add that the charter may contain "any provisions not inconsistent with law which the incorporators may choose to insert for the regulation of the internal affairs of the corporation and the business of the corporation." 22 Other statutes are somewhat more wordy. The Delaware statute is perhaps typical. It states that the articles may contain "any provision which the incorporators may choose to insert for the management of the business and for the conduct of the affairs of the corporation, and any provisions creating, defining, limiting and regulating the powers of the corporation, the directors and the stockholders, or any class of the stockholders."23

These general statutory provisions authorizing special charter clauses appear on their face to permit great flexibility in charter drafting and to furnish ample authority for inserting clauses requiring unanimity or a greater than customary vote for shareholder and director action. On the basis of these statutes alone, however, the assumption must not be too readily made that clauses of that type can be safely inserted in the charter. In most jurisdictions, the courts have not as yet interpreted these broadly worded statutes to determine just what charter provisions are authorized. ${ }^{24}$ Further, most of the statutes authorizing special provisions limit the authorization to "lawful provisions," "provisions not inconsistent with law," or provisions which do not exempt shareholders, directors or members "from the per-

${ }^{21}$ E.g., Cal. Corp. Code $\$ 3900$ (I948); Tenn. Code $\$ 3748$ (Michie, I932). See also Note, $5^{1}$ Hanv. L. REv. 1074 (1938). In the absence of statute, authority to execute corporate mortgages is vested in the directors alone, but apparently a charter provision requiring shareholder consent is valid. Liverpool \& London \& Glove Ins. Co. v. Aleman Planting and Mfg. Co., r66 La. 457, Ir7 So. 554, 556-7 (1928); Bishop v. Kent \& Stanley Co., 20 R. I. 680, 4 I Atl. 255 (I898).

22 E.g., PA. Bus. Corp. L. \$204. See also Ill. Stat. c. 32, \$157.47(I) (Smith-Hurd, Supp. 1952); Mo. Rev. Stat. \$351.055 (1949).

${ }^{23}$ Del. Gen. Corp. L. $\$ 5(8)$. See also, sections 5 (II), I3, and I7 of that statute. N. Y. GeN. Conp. L. $\$ \mathrm{I}_{3}(2)$ states that a corporation's certificate of incorporation may contain "any provision for the regulation of its business and the conduct of its affairs, and any limitation upon its powers, or upon the rights of its stockholders or upon the power of its directors and members, which does not exempt them from the performance of any obligation or duty imposed by law." OHIO. GEN. CODE $\$ 8623-4(8)$ (Supp. 1952) provides that "any lawful provisions which may be desired for the purpose of defining, limiting and regulating the exercise of the authority of the corporation, or of the directors or of all the shareholders" may be included in the articles and that "any provision authorized to be made in the regulations of a corporation may, if desired, be made in its articles."

24 See Ballantine, Corporations \$I6 (rev. ed. I946); Ballantine and Sterling, Califormia Corporation Laws $\$ 37$ (1949 ed.). For interesting cases on the legality and effect of optional provisions in the articles, see Union Trust Co. of Maryland v. Carter, 139 Fed. 7 17 (C.C.W.D. Va. 1905); State ex rel. Ross v. Anderson, 3 I Ind. App. 34, 67 N. E. 207 (r903). 
formance of any obligation or duty imposed by law." These vague phrases may encourage courts to hold charter veto clauses unlawful as violative of other statutes or as inconsistent with the established scheme of corporate management or contrary to some obscure public policy. ${ }^{25}$

In most states, reliance does not have to be placed solely on the statutes authorizing special provisions; other and more specific statutes also support the validity of high vote requirements. Perhaps the best known of the statutes expressly applicable to high vote requirements is Section 9 of the New York Stock Corporation Law. ${ }^{26}$ That statute, enacted on the recommendation of the New York Law Revision Commission, was hailed at the time of its passage as the first important legislative recognition of the special management needs of closely held corporations. ${ }^{27}$ It provides that (subject to compliance with certain requirements of consent by shareholders) the certificate of incorporation ${ }^{28}$ can impose high quorum requirements for shareholders' meetings and for directors' meetings, and can require unanimity or a vote greater than a majority for shareholder and director action. Section 9 originally limited the validity of veto provisions of this kind to ten years, after which they could be renewed for one or more ten year periods. As amended, ${ }^{29}$ however, that statute apparently permits these arrangements to remain in effect for an unlimited period of time.

2. Statutes Applicable Solely to Shareholder Action. Many modern corporation acts expressly authorize charter provisions requiring a high vote for shareholder action. The Delaware statute, for instance, provides that the certificate of incorporation may contain "provisions requiring for any corporate action the vote of a larger proportion of the stock or of any class thereof than is required by this Chapter." Similarly, the Model Business Corporation Act ${ }^{31}$ contains a section which states: ${ }^{22}$

Whenever, with respect to any action to be taken by the shareholders of a corporation, the articles of incorporation require the vote or concurrence of the holders of a greater proportion of the shares, or of any class or series thereof, than required by this Act with respect to such action, the provisions of the articles of incorporation shall control.

Statutes substantially the same as this provision from the Model Act can be found in the laws of a number of important commercial jurisdictions, ${ }^{33}$ and no case has

${ }^{25}$ See Kaplan v. Block, $x 83$ Va. 327, 3 I S. E. $2 d 893,897$ (1944), discussed infra page $46 \mathrm{r}$.

${ }^{20}$ N. Y. Stock Corp. Law $\$ 9$ added by N. Y. L. c. 862 , $\$$ I (1948), amended by N. Y. L. c. 261 (1949) and N. Y. L. c. 717, \$I (195I).

${ }_{27}$ Capriles and Reichardt, 1947-1948 Survey of New York Law-Corporations, 23 N. Y. U. L. Q. REv. 747 (1948).

${ }^{28}$ Note should be taken of the fact that Section 9 does not provide for the imposition of high quorum or voting requirements by shareholders' agreement or by-law provision.

${ }^{20}$ N. Y. L. c. 717, \$I (I95I).

${ }^{30}$ Ded. Gen. Corp. L. $\$ 5$ (Ir). See also Del. Gen. Corp. L. \$17.

31 Prepared by the Committee on Business Corporations of the Section of Corporation, Banking and Business Law of the American Bar Association.

${ }_{32}$ MOdeI Bustness CORP. ACT $\$ 136$ (1950).

${ }^{33}$ E.g., Ilx. Stat. c. 32, \$157.I46 (I935); Mo. Rev. Stat. $\$ 351.270$ (1949). The Ohio statute, Ono GeN. CODE $\$ 8623-49$ (1938), states: "Notwithstanding any provision of this act requiring for any purpose the vote of a designated porportion of the voting power of a corporation, or of any class 
been found in which the validity of this kind of statute has been challenged. ${ }^{34}$

Some states have statutory provisions permitting a high vote requirement for specified shareholder action. Representative statutes of this kind require a stated shareholder vote for charter amendment, consolidation, merger, and sale of assets, but add that the stated vote may be increased by charter provision. ${ }^{35} \mathrm{~A}$ particular jurisdiction may have this kind of statute in lieu of, or in addition to, a statute authorizing a high vote requirement for any shareholder action.

3. Statutes Applicable Solely to Director Action. In many jurisdictions, the corporation statutes expressly state that the charter many require greater than a majority vote for director action. The Model Business Corporation Act ${ }^{36}$ and the corporation laws of a number of important jurisdictions ${ }^{37}$ contain a section which states that the "act of the majority of the directors present shall be the act of the board of directors, unless the act of a greater number is required by the articles of incorporation or the by-laws." This language seems clearly to authorize inclusion in the charter of provisions requiring the vote of more than a majority of the directors present for any director action or for particular kinds of action. Even in jurisdictions in which the corporation statute does not contain this clear authorization, a charter provision requiring a high director vote would probably be given effect. $^{38}$

\section{B. Statutes Authorizing Provisions in the By-Laws}

The corporation statutes in many states contain general provisions (similar to those inviting the inclusion of special clauses in the charter) which seem sufficiently broad to authorize the insertion in the by-laws of provisions requiring unanimity or a high percentage vote for director action and perhaps for shareholder action. Some statutes provide that the by-laws may include "any lawful provisions which may be desired for the purpose of defining, limiting and regulating the exercise of authority of the corporation, or of the directors or of all the shareholders."39 Other statutes state that the by-laws may contain "any provisions for the regulation

or classes of the shares thereof, the articles of a corporation may provide that such action may be taken by the vote of a greater or less proportion of such voting power of such corporation, or by the vote of any class or classes of the shares thereof than that so required by this act, but, unless expressly permitted by this act such proportion shall not less than a majority." "Voting power" in this provision undoubtedly refers solely to voting by shareholders, not to voting by directors; this is suggested by the context, this provision being in that portion of the act relating to shareholders.

34 Aldridge v. Franco Wyoming Oil Company, 24 Del. Ch. 349, 14 A.2d 380 (1940), however, has the effect of limiting the Delaware statute. See discussion of that case infra page 467 . (1938).

${ }^{35}$ See, e.g., WIs. Bus. CoRp. L. $\$ \$ 180.5 \mathrm{I}$, I80.64, I80.7I (r95I). Cf. OHIo Gen. Code $\$ 8623-15$

${ }^{30}$ Section 37.

${ }^{37}$ E.g., Il.l. Stat. c. 32, \$157.37 (Smith-Hurd, 1935); OHo GeN. Code \$8623-58 (1938); Wis. Bus. CoRp. L. $\$ 180.35$ (195I).

38، Apart from statute... there is nothing in the nature of the corporation to prevent the shareholders from committing the management of the company's business and affairs to a board or other select group, but requiring that such board can act with legal effect only with unanimity." Ballard, Arrangements for Participation in Corporate Management Under the Pennsylvania Business Corporation Law, 25 TEMP. L. Q. 131, 152 (195X).

${ }^{30}$ E.g., Ohio GeN. CoDe $\$ 8623^{-12}$ (Supp. 1952). 
and management of the affairs of the corporation not inconsistent with law or the articles of incorporation." 40 Further, in some states the corporation statute contains provisions that even more clearly indicate that high vote requirements may be inserted in the by-laws. A typical provision states that the act "of the majority of the directors present at a meeting at which a quorum is present shall be the act of the board of directors, unless the act of a greater number is required by . . . the by-laws." 41

\section{IV}

\section{Unfavorable Statutes and Decisions}

The validity of charter and by-law provisions requiring unanimity or a high vote for shareholder or director action may be challenged on the ground that they (I) contravene statutory provisions specifying the shareholder or director vote necessary for particular corporate acts, (2) are inconsistent with the general scheme of corporate management, ${ }^{42}$ or (3) violate public policy in that they make difficult the conduct of corporate business and may lead to corporate paralysis. ${ }^{43}$

In most states, challenges of this kind have little chance of prevailing because of the clearly worded statutes (discussed in the preceding section of this paper) authorizing charter or by-law requirements fixing a high vote for shareholder and director action. In a few jurisdictions, however, such requirements if challenged would probably be held invalid. In one or two states, the corporation statute contains provisions on shareholder or director voting so worded that the courts may well conclude that the voting procedures there set forth are inflexible and that voting requirements cannot be increased by charter or by-law provision. The New Jersey statute is an example. It lays down procedures to be followed in charter amendment, merger, consolidation, dissolution, and similar corporate action, ${ }^{44}$ an essential step in each of these procedures being a favorable vote of a specified percentage of the shares or of the shares with voting power. In each instance the voting requirement is couched in language which appears to permit no variation. ${ }^{45}$ Further, the New Jersey courts have indicated rather positively that they will not permit a modification of the statutory vote. ${ }^{40}$

${ }^{10}$ E.g., Mo. Rev. Stat. $\$ 351.290$ (1949). Cf. PA. Bus. Corp. L. $\$ 304$ (I95T).

${ }^{42}$ Ill. Stat. c. 32, \$157.37 (I935); Ohio GeN. Code \$8623-58 (I938); Wis. Bus. Corp. L. 5180.35 (195I)

${ }^{2}$ See Jackson v. Hooper, 76 N. J. Eq. 592, 75 Atl. 568, 57 I (1910).

${ }^{43}$ See Kaplan v. Block, 183 Va. 327, 31 S. E. 2d 893, 896-7 (r944). In commenting on Benintendi v. Kenton Hotel, 294 N. Y. x12, 60 N. E. 2 d 829 (1945), discussed infra page 462 , the Attorncy Gencral of New York stated: "It seems to me that the essence of the decision is to the effect that since requirements for unanimity in matters involving the stockholders' and directors' activities render it virtually impossible to coniduct the normal operations of the corporation, they are, in the absence of specific statutory authority therefor violative of the public policy of this State." Op. Att'y Gen. (N. Y.) to Sec'y of State $(12-14-48)$.

${ }^{4}$ N. J. REv. STAT. §§I $4: 11-2,14: 12-2,14: 12-3,14: 13-1$ (1937).

${ }^{45}$ E.g., "If two-thirds in interest of each class of stockholders having voting powers shall vote in favor of such amendment, change or alteration, the corporation shall make a certificate thereof. . . ." N. J. Rev. STAT. \$r4:Ix-2 (I937).

so "Our Corporation Act provides ... that a vote of two-thirds of the holders is sufficient for 
Note should be taken of the fact that the New Jersey laws contain a typical provision authorizing the inclusion of special provisions in the certificate of incorporation. ${ }^{47}$ The New Jersey courts, however, have not referred to that provision when they have discussed the legality of charter and by-law stipulations varying the statutory votes, and apparently they do not think that it is pertinent to the problem.

Even in states with corporation laws which in general permit great flexibility in the management pattern, clauses requiring unanimity or a qualified majority may be of questionable validity if applied to some corporate acts. For example, the Pennsylvania corporation statute, which in general allows considerable flexibility, contains a section ${ }^{48}$ that reads as follows: $:^{49}$

No business corporation shall increase its indebtedness, except in the manner provided in this section. The board of directors of the corporation shall adopt a resolution setting forth the desired increase, and directing that the question of the proposed increase be submitted to a vote at an annual meeting of the shareholders or at a special meeting of the shareholders.... The resolution shall be adopted upon receiving the affirmative vote of the holders of at least a majority of the outstanding shares. . . [italics supplied].

The courts might invalidate a charter or by-law provision requiring a higher shareholder vote than one set forth in this section. Perhaps a point that should be made here is that the lawyer planning veto provisions cannot safely rely on general statutory provisions that seem to permit unlimited flexibility in charter or by-law clauses; he must comb the laws of the state for other statutory provisions which lay down rigid procedures for particular types of corporate action and can be interpreted as limiting the more general and less rigid provisions.

Among the courts which have shown hostility to provisions requiring approval by a high percentage of shareholders or directors for effective corporate action is the Virginia Court of Appeals. In Kaplan v. Block, ${ }^{50}$ that court held invalid a charter provision providing that acts of the board of directors were not to bind the corporation or the shareholders until they were ratified by the unanimous vote of holders of outstanding stock. ${ }^{51}$ The Virginia corporation statute contained at the time of this decision, as it still does, a provision permitting inclusion in the certificate of in-

amendments of the certificate of incorporation, dissolution, merger, and other important corporate matters. . . A certificate or by-laws which would require unanimous vote on these matters would be subversive of the statute." Clausen v. Leary, Ir3 N. J. Eq. 324, I66 Atl. 623, 625 (I933). This language was referred to with approval in Warren v. 536 Broad Street Corporation, 4 N. J. Super. 584 , 68 A. 2d 175, 180 (1949), aff'd, 6 N. J. Super. 170, 70 A.2d 782 (1950). See also Jackson v. Hooper, 76 N. J. Eq. 592, 75 Atl. 568, 57I (1910).

${ }^{4}$ N. J. REv. STAT. $\$ \times 4: 2-3$ (1937).

${ }^{48}$ Pa. Bus. Corp. L. $\$ 309$ (I95Y).

${ }^{40} \mathrm{With}$ this provision compare PA. Bus. CoRP. L. $\S_{31 \mathrm{II}}(\mathrm{B})$ (voluntary transfer of corporate assets), $\$ 902$ (approval of joint plan of merger or consolidation), \$1102 (voluntary dissolution). For sections of the Pennsylvania statute indicating clearly that the statutory procedure there fixed can be modified, see PA. Bus. Corp. L. $\$ 3^{\circ} 4, \$ 406$ (electing and fixing the compensation of officers), $\$ 503$ (quorum of sharcholdcrs), $\$ 60 \mathrm{I}$ (issuance of stock), $\$ 805$ (amendment of articles by shareholders).

${ }^{50}{ }_{18}$ Va. 327, 3 I S. E. $2 d 893$ (1944).

${ }^{61}$ Compare Kaplan v. Block, with Union Trust Co. of Maryland v. Carter, 139 Fed. 7I7 (C.C.W.D. Va. I905), upholding a charter provision by which the shareholders in a Virginia corporation bound themselves in advance to affirm for a specified period of time all acts of the directors. 
corporation of optional clauses "creating, defining, limiting or regulating the powers of the corporation, of the directors or of the stockholders."52 Further, the section of the corporation statute that defined the powers of the board of directors clearly indicated that those powers could be modified by "any by-law or regulation of the stockholders." ${ }^{\text {I53 }}$ In spite of these statutory provisions, the Court of Appeals asserted that "the board of directors must direct the business, and govern the policy and plans of the corporation," and declared the charter provision void as an attempt to "sterilize" the board of directors. ${ }^{54}$

Although the charter provision in the Kaplan case is easily distinguished from one requiring unanimity or a high percentage vote for shareholder action, considerable language in that case and some of the materials quoted with approval in that decision suggest that the court would not have sustained a requirement of unanimity or high vote. In particular, the court recognized a "right" of majority rule in corporate affairs; ${ }^{55}$ and, after discussing business considerations against giving a single individual power to render the corporation helpless, it asserted unequivocally that charter provisions giving such a power "violate both common and statute law and are suicidal of corporate existence."

Benintendi $v$. Kenton Hotel ${ }^{57}$ has been overruled by statute, ${ }^{58}$ but the reasoning of that decision is still significant because the approach there taken may be followed by courts in jurisdictions where the legislature has not spoken. In that decision, the New York Court of Appeals held invalid (I) a by-law requiring unanimity for shareholders' resolutions, (2) a by-law requiring unanimity for the election of directors, and (3) a by-law requiring unanimity for directors' resolutions. ${ }^{69}$ The three by-laws were thought to be inconsistent with controlling corporation statutes. By-law (I), requiring unanimity for shareholder action, was "obnoxious to the statutory scheme of stock corporation management."60 Among other things, it violated statutes ${ }^{61}$ fixing stated percentage votes for specified resolutions, e.g., resolutions in proceedings to change a corporation's capitalization or to dissolve it. By-law (2), requiring a unanimous stock vote for the election of directors, was also

${ }^{52}$ VA. CODE $\$ 13-24(9)$ (Michic, 1950).

${ }^{53}$ VA. CODE \$r 3-200 (Michie, r950).

54 "To ask that directors be divested of all power and that without the consent of every stockholder no one should have the power to do anything is to ask too much." 31 S. E. 2d at 897. The court relied heavily on an earlier decision, Sterling v. Trust Co. of Norfolk, I49 Va. 867, I41 S. E. 856 (1928).

${ }^{55} 3$ I S. E. 2d at 896 .

Id. at 896-897.

${ }^{57} 294$ N. Y. II2, 6o N. E. 2d 829 (1945).

${ }^{68}$ See N. Y. STK. CoRp. L. $\$ 9$, discussed stupra page 458 . The statement in the text is not entircly accurate. The Benintendi decision invalidated veto provisions in the by-laws but on grounds broad enough to invalidate also veto provisions in the charter. The statute authorized the insertion of veto provisions in the charter.

${ }^{50}$ The doctrine of the Benintendi case was later extended to by-laws requiring less than unanimity but more than a majority. Christal v. Petry, 301 N. Y. 562, 93 N. E. 2d 450 (r950); Eisenstadt Bros. v. Eisenstadt, 89 N. Y. S. $2 d$ I2 (Sup. Ct., Spec. T., Queens Co. 1949). But see Kronenberg v. Sullivan County Steam Laundry Co., 9I N. Y. S. 2d 144 (Sup. Ct., Sullivan Co. 1949).

${ }^{60}$ ". . . this State has decreed that every stock corporation chartered by it must have a representative government, with voting conducted conformably to the statutes. ..." 6o N. E. $2 \mathrm{~d}$ at $83 \mathrm{I}$.

${ }^{61}$ N. Y. STK. CORP. L. $\$ \$_{3} 6,37 ;$ N. Y. GEN. CORP. L. \$102. 
held to violate a statutory norm, namely a section of the Stock Corporation Law providing that directors shall be chosen by a plurality of the votes cast. ${ }^{62}$ By-law (3), requiring unanimity for directors' acts, was referred to as "almost as a matter of law, unworkable and unenforcible," and was held to violate the statutory scheme of corporate management established by Sections 27 and 28 of the New York General Corporation Law. This conclusion was reached in spite of language in each of those sections which seemingly permitted departure from the statutory pattern. ${ }^{63}$

Although the veto provisions declared invalid in the Benintendi case were in the by-laws, the reasoning of the decision was broad enough to invalidate those provisions even had they been included in the charter. ${ }^{64}$ The majority opinion did not mention New York statutes authorizing the inclusion of special clauses in the certificate of incorporation ${ }^{65}$ and permitting voting rights to be spelled out in the charter. ${ }^{66}$ The members of the court, however, undoubtedly were well aware of those statutes $;^{67}$ and apparently the majority judges were of the opinion that in spite of those statutes the broad principles laid down in the decision were applicable to charter provisions as well as to by-laws. ${ }^{68}$

${ }^{02}$ N. Y. STK. Corp. L. $\$ 55$. The court cited with approval In re Boulevard Theatre \& Realty Co., 195 App. Div. 518, 186 N. Y. S. 430 (Ist Dep't I921), aff'd, 23 r N. Y. 615, r32 N. E. 910 (r92I), and In re Election of Directors of Rapid-Transit Ferry Co., I5 App. Div. 530, 44 N. Y. S. 539 (2d Dep't 1897), cases which respectively invalidated a charter provision and a by-law provision as being inconsistent with Scction 55 .

${ }^{03}$ Section 27 reads as follows: "The business of a corporation shall be managed by its board of directors. . . . Unless otherwise provided a majority of the board at a meeting duly assembled shall be necessary to constitute a quorum for the transaction of business and the act of a majority of the dircctors present at such a meeting shall be the act of the board. The by-laws may fix the number of directors necessary to constitute a quorum at a number less than a majority of the board, but not less than one-third of its number" (italics supplied). Perhaps the court was of the opinion that the phrase "Unless otherwise provided" applied only to the clause immediately following it and not to that part of the sentence which provides for majority action by directors. That interpretation would permit fexibility in fixing the quorum (subject to the limitation in the last sentence of the quoted extract) but would not allow variation in the voting requirement. On the other hand, the section could easily have been interpreted to grant flexibility in setting both quorum and voting requirements, subject to the single exception that the quorum could not be reduced below one-third.

Section 28 seems to provide even more clearly for flexibility. That section states that whenever "under the provisions of any corporate law a corporation is authorized to take any action by its directors, action may be taken by the directors, regularly convened as a board, and acting by a majority of a quorum, except when otherwise expressly required by law or the by-laws. . . " (italics supplied). Statutory provisions similar to Sections 27 and 28 are to be found in the laws of other states. See, e.g., PA. Bus. CORP. L. $\$ 402$ (5) (195I).

"Note for example the following language: "That whole concept [representative corporate government conformable to statute] is destroyed when the stockholders, by agreement, by-law or certificate of incorporation provision as to unanimous action, give the minority interest an absolute, permanent, allinclusive power of veto." 60 N. E. $2 \mathrm{~d}$ at 831 . See also Eisenstadt Bros. v. Eisenstadt, 89 N. Y. S. 2d 12, 13 (Sup. Ct., Spec. T., Queens Co. r949).

${ }^{\mathrm{O}} \mathrm{N}$. Y. Gen. CoRp. L. \$13(2).

${ }^{68}$ N. Y. STock CoRP. L. $\$ ₫ I I, 5 \mathrm{I}$.

${ }^{\text {or }}$ See the dissenting opinion in Benintendi v. Kenton Hotel, 294 N. Y. II2, 60 N. E. 2 d 829,832 , 834-5 (1945).

os But note the following extract from Op. Att'y Gen. (N. Y.) to Sec'y of State (I2-I 4-48): "The provisions of the corporation laws of this State which have long been deemed to authorize requirements for stockholder approval in excess of that which would otherwise be necessary, namely, $\$ \S \mathrm{I}$ and 51 of the Stock Corporation Law and $\$ 13$ of the General Corporation Law, were not cited to the court in the Benintendi case or referred to in its decision. Therefore, it would not appear that the Benintendi decision invalidated the certificate provisions here involved." 
High Quorum Requirements for Shareholders' and Directors' Meetings

Many corporation statutes authorize charter or by-law provisions fixing high quorum requirements for meetings of shareholders and directors, ${ }^{00}$ and provisions of that kind are probably valid even in the absence of statutory authorization. Therefore, some draftsmen, with a view to conferring a veto, insert in the charter or by-laws provisions requiring the presence of a high percentage of shareholders or directors for quorums for the transaction of any business or of designated kinds of business. To protect shareholders or directors against their appearing inadvertently at a meeting that is to consider action they oppose, the high quorum requirement must be buttressed by a requirement that notices of meetings state the business that is to be transacted. Otherwise, a shareholder or director may attend a meeting, help form a quorum, and thus permit action on a matter he opposes.

Many lawyers apparently are of the opinion that the use of both high quorum and high vote requirements sets up a double hurdle that objectionable action must clear before it will be operative. Actually, this double obstacle is an illusion. If a shareholder or director refrains from attending a meeting in order to prevent the forming of a quorum, he of course never gets an opportunity to veto a proposal by voting against it. In most situations, it is preferable to rely solely on a high vote requirement. That permits shareholders or directors in apparent disagreement to get together, discuss their differences, and possibly discover areas of agreement or evolve policies satisfactory to all.

A few statutes, however, contain provisions that suggest a possibly sound reason for the practice of using both high quorum and high vote requirements. For example, some corporation statutes contain a section ${ }^{\text {70 }}$ that reads:

Whenever, with respect to any action to be taken by the shareholders of a corporation, the articles of incorporation require the vote or concurrence of the holders of a greater proportion of the shares, or of any class or series thereof, than required by this Act with respect to such action, the provisions of the articles of incorporation shall control. [italics supplied].

In view of this statutory language, there is some doubt that a requirement of unanimity for shareholder action (as distinguished from a requirement of a high percentage vote) is valid. The words "greater proportion" could conceivably be given a narrow, literal interpretation that would exclude by implication the use of requirements of unanimity. The language of most statutory provisions authorizing an increase in quorum requirements is not open to this narrow interpretation. ${ }^{71}$

${ }^{60}$ E.g., Mo. Rev. Stat. $\$ \$ 351.265,351.325$ (1949); N. Y. StK. CoRp. L. \$9; Wis. Bus. Corp. L. $\$ \S 80.28,180.35$ (I95r).

${ }^{70}$ Model Bus. Corp. Act $\$ 136$ (1950); Wis. Bus. Corp. L. $\$ 180.90$ (1951). See also Ded. Corp. I. $\$ 5(I I)$; OhIo. GeN. Code ANN. \$8623-49 (1938).

${ }^{7}$ Sec, e.g., MOdel Bus. CoRP. ACT $\$ 30$ (I950). 


\section{Where Veto Provisions Should Be Placed}

Provisions requiring a high vote or setting high quorum requirements ordinarily should be placed both in the charter and in the by-laws. There are a number of reasons for inserting provisions of that kind in the charter. If they are included in the charter, express statutory authority can usually be found to support their validity. ${ }^{72}$ As a matter of fact, some statutes clearly indicate that certain veto provisions will not be effective unless they are in the charter. ${ }^{73}$ Further, some courts seem to be more willing to sustain veto provisions if they are in the charter than if they are in the by-laws. ${ }^{74}$

In most situations, veto provisions should also be included in the by-laws. Some cases have held that in the absence of statutory permission the provisions of the charter must be confined to those required by law and that additional clauses inserted in the articles will be treated as surplusage. ${ }^{75}$ As the corporation statutes of some states do not expressly authorize special charter provisions, there is some danger that special provisions in charters of corporations formed in those states will not be given effect. Further, some corporation statutes refer only to the use of by-law provisions as a method of increasing voting or quorum requirements for director action; they do not mention variation by charter provision. An example is the Pennsylvania statute, which contains a section stating that "except as otherwise provided in the by-laws . . . a majority of the directors in office shall be necessary to constitute a quorum for the transaction of business, and the acts of a majority of the directors present at a meeting at which a quorum is present shall be the acts of the board of directors."76 The inference could easily be drawn from this statute that increased quorum or voting requirements for action by the directors, irrespective of whether they are included in the charter, will not be effective unless stated in the by-laws. Thus, the interesting point is made that in some jurisdictions provisions designed to afford a veto over some kinds of corporate action, e.g., changes in salaries or other action within the province of the directors, have greater statutory support if inserted in the by-laws; while provisions giving a veto over other kinds of action, e.g., fundamental changes in the corporate structure that require a shareholder vote, have stronger statutory support if they are included in the charter. ${ }^{77}$

${ }^{72}$ E.g., Del. Gen. Corp. L. $\$ 5(I x)$; N. Y. StK. Corp. L. \$9; Ohio Gen. Code ANn. \$8623-49 (I938); Wis. Bus. CoRp. L. $\$ 180.90$ (I95I).

${ }_{73}$ E.g., PA. Bus. CoRp. L. $\$ 503$ (I95I); Wis. Bus. CoRp. L. \$I80.28 (I951). See Ballard, Arrangements for Participation in Corporate Management Under the Pennsylvania Business Corporation Law, 25 TEMP. L. Q. I31, I62-163 (195x).

"Compare Benintendi v. Kenton Hotel, 294 N. Y. Ir2, 60 N. E. 2d 829 (I945) (holding invalid by-laws requiring unanimity for shareholder or director action), with Ripin v. Atlantic Mercantile Co., 205 N. Y. 442,98 N. E. 855 (I912) (sustaining a charter provision stating that the number of directors could not be changed except by unanimous consent of the shareholders). The decision in the Ripin case was grounded on a general statute authorizing the inclusion of optional provisions in the charter.

${ }^{75}$ Renn v. United States Cement Co., 36 Ind. App. I49, 73 N. E. 269 (1905); Sherman Center Town Co. v. Morris, 43 Kan. 292, 23 Pac. 569 ( 1890$).$

${ }^{70}$ PA. Bus. CoRp. L. \$402 (I95I).

${ }^{37}$ Compare PA. Bus. CoRp. L. $\$ 402$ (195I) (fixing a statutory quorum for directors' meetings but 
Even in jurisdictions in which the inclusion in the charter of all veto provisions necessary for desired control is clearly authorized, it may still be advantageous to repeat the provisions in the by-laws. By-laws serve as a guide for directors and officers in the conduct of corporate activities; consequently, veto provisions placed there are constantly before the attention of the directors and officers.

\section{VII}

\section{Precautions That Strengthens Veto Provisions}

\section{A. Limitation of Veto to Area of Business Need}

As a general proposition, the power to veto should be limited to those corporate activities over which a veto is needed to protect legitimate business interests. In most situations, the conferring of a blanket power to veto any or all corporate acts is inadvisable because the existence of that power enhances the chance of deadlock and corporate paralysis. Further, there is probably a greater risk that the courts will invalidate a general veto over all shareholder or director action than a veto over a particular act or over a limited number of specified acts. ${ }^{78}$ This increased risk of invalidity is attributable in the final analysis to the possibility that courts will take a dark view of the business wisdom of blanket powers of veto and (rightly or wrongly) will let that business judgment influence their decisions on the validity of the veto provisions.

Whenever a charter or by-law provision is intended to provide a veto only over particular corporate acts, care should be taken that the limited nature of the veto is clearly expressed. Courts cannot be depended on to interpret the provisions so as to restrict their applicability to corporate acts legally subject to veto. ${ }^{79}$

\section{B. Obtaining Unanimous Consent to Establishment of Veto}

A power of veto usually should not be provided unless all the participants agree to it at the time of its creation. Great caution must be exercised in departing from customary corporate practices, and this is particularly true if some of the participants oppose the departure. At the time a corporation is being formed, the participants as a part of their business bargain usually reach agreement on the pattern of control. If a veto is not agreed on at that time, it is doubtful that the charter or by-laws should be amended thereafter to insert veto provisions to which minority share-

authorizing variation of the quorum in the by-laws), with PA. Bus. Corp. L. $\$ 503$ (1951) (sctting a quorum for shareholders' meetings but authorizing variation of the quorum by provision in the articles).

${ }^{78}$ Compare Benintendi v. Kenton Hotel, 294 N. Y. I12, 60 N. E. 2d 829 (1945) (holding invalid by-laws requiring unanimity for all shareholder and director action) with Ripin v. Atlantic Mercantile Co., 205 N. Y. 442,98 N. E. 855 (I912) (sustaining a charter provision stating that the number of directors could not be changed except by unanimous consent of the shareholders). The court in the Benintendi case expressly stated that the holding there did not mean "that an arrangement would necessarily be invalid, which for particular decisions, would require unanimous consent of all stockholders." 60 N. E. $2 \mathrm{~d}$ at $83 \mathrm{r}$.

${ }^{70}$ In Benintendi v. Kenton Hotel, 294 N. Y. II2, 60 N. E. 2d 829 (1945), a by-law requiring unanimity for shareholder action could possibly have been sustained against the objection that it violated statutory norms specifying the shareholder vote for certain corporate acts, if the courts had construcd it as applicable only to corporate acts not specified by statute to require a stated vote. Sec Note, $48 \mathrm{MicH}$. L. REv. 875 (1950) and discussion of the Benintendi case supra page 462 . 
holders object. The risk that a provision will be declared invalid is probably increased by dissent at the time of its adoption. Some courts may be willing to uphold deviations from the statutory pattern of control that are agreed to by all interested persons on the theory that the shareholders by unanimous consent can do as they please with the corporation provided creditors are not prejudiced, but may not be willing to allow departures from the statutory pattern if there are dissenters. ${ }^{80}$

\section{Care in Framing Veto Provisions}

A veto provision that will be sustained if worded in one way may be invalidated if couched in different language. This point is illustrated by Aldridge v. Franco Wyoming Oil $\mathrm{Co}^{81}$ The charter provision before the court in that case stated that "no person shall be elected a director of the Corporation against whom there shall be cast the votes of forty percent ( $40 \%$ ) in amount of the outstanding Class A stock." Although the court apparently recognized that the charter could require for shareholder action the approval of greater than a majority of all shares or the approval of a high percentage of a specified class of shares, ${ }^{82}$ it invalidated the charter provision under consideration. It interpreted the provision to require two elections for directors, one in which all shareholders voted for the directors of their choice and a second in which the holders of the Class A stock expressed approval or disapproval. According to the court, the provision was "not susceptible to the construction that, to effect the election of a director, the candidate must receive the vote of a majority of the common stock and the vote of more than sixty percentum of the Class A stock." ${ }^{\text {" } 3}$ The court then drew a distinction between a "voting right" and a "right to veto," and held that a right to veto "is not within the intendment of the law as it is now written." 84

The draftsman must also keep in mind that veto provisions are likely to be strictly construed. At least one court has warned that charter provisions departing from majority rule will be given effect only if they are clear, explicit and susceptible of but one reasonable interpretation. ${ }^{85}$ Therefore, veto provisions must be couched in language free from any ambiguity. A provision requiring unanimity for shareholder

${ }^{\text {Bo }}$ Of interest is Bechtold v. Coleman Realty Co., 367 Pa. 208, 79 A. 2d 66I (I95I), recognizing two classes of by-laws: ( $I$ ) mere regulations governing the conduct of the internal affairs of the corporation, which may be repealed or amended by majority vote unless a greater vote is specified by the by-laws or by statute, and (2) provisions in the nature of a contract evidently designed to vest property rights, which cannot be repealed or changed without the consent of the parties whose rights are affected. Is corporate control a type of property right which would lead a court to place in the second classification a by-law setting the vote for sharcholder or director action, and thus to require unanimous consent for an amendment increasing the vote fixed in the by-law?

${ }_{24} 24$ Del. Ch. 349 , 14 A. 2 d 380 (I940).

${ }^{82}$ In view of DEL. CoRp. L. $\$ \$ 5$ (II), I7, a contrary conclusion could hardly have been reached. DEL. Conp. L. $\$ 5$ in listing what the certificate of incorporation shall set forth, expressly states in paragraph II that it may contain "provisions requiring for any corporate action the vote of a larger proportion of the stock or any class thereof than is required by this Chapter." See also Sellers v. Joseph Bancroft \& Sons Co., 23 Del. Ch. I3, 2 A. 2 d ro8 (r938), r7 A. 2d 831 (Del. Ch. I94r). These authorities, however, were not referred to in the Aldridge case.

${ }^{83} \mathrm{I}_{4}$ A. $2 \mathrm{~d}$ at $3^{8 \mathrm{r}}$.

Bt 7 bid.

${ }^{80}$ Standard Power \& Light Corp. v. Investment Associates, 5x A. 2d 572, 576 (Del. Sup. Ct. I947). 
action, for instance, should be so worded that there can be no question that approval of holders of all shares outstanding is necessary, not just approval of shares present or represented at a shareholders' meeting. ${ }^{86}$

D. Using High Vote Requirements in Preference to Requirements of Unanimity

A provision requiring unanimity for shareholder or director action is perhaps a little less likely to be sustained than is a high vote requirement. ${ }^{87}$ Some statutory provisions authorizing increases in the voting requirements fixed by statute for shareholder action do so in terms that can be construed as excluding requirements of unanimity. As has been mentioned ${ }^{88}$ some statutes authorize the use in the charter of provisions fixing the vote necessary for shareholder action at "a greater proportion of the shares" than is otherwise required by law. This language provides a convenient peg on which to hang a decision invalidating a requirement of unanimity. A Delaware court has suggested that a provision requiring unanimity for shareholder action may be invalid ${ }^{89}$ under the Delaware statute, which states that the charter may include "provisions requiring for any corporate action the vote of a larger proportion of the stock or any class thereof" than is otherwise fixed by the statute. ${ }^{00}$ In some situations, therefore, it may be advisable to use a percentage requirement rather than a requirement of unanimity even though the favorable vote required for action must be set at an unusually high percentage in order to provide the veto. In other words, if a power of veto is to be given to a shareholder owning II per cent of the stock, it may be better to require for shareholder action concurrence of holders of 90 per cent of the shares rather than unanimity. ${ }^{01}$ Whenever a high vote requirement (as distinguished from a requirement of unanimity) is used, however, safeguards must be set up against the issuance of additional shares that will decrease the proportionate holdings of shareholders having a power of veto. ${ }^{92}$

\section{E. Reference to Veto Provisions on Share Certificates}

Appropriate reference to veto provisions should be made on each share certificate. The object of this of course is to preclude purchasers of shares from claiming that they were unaware of the veto provisions at the time they bought their shares and

${ }^{\mathrm{so}}$ See Investment Associates v. Standard Power and Light Corp., 29 Del. Ch. 225, 48 A. $2 \mathrm{~d} 501$ (1946), aff'd, 51 A. 2d 572 (Del. Sup. Ct. I947).

${ }_{87}$ In Kronenberg v. Sullivan County Steam Laundry Co., 9r N. Y. S. 2d 144 (Sup. Ct., Sullivan Co. I949), the court distinguished Benintendi v. Kenton Hotel, 294 N. Y. I12, 60 N. E. 2d 829 (1945), discussed supra page 462 , and sustained a clause in the certificate of incorporation requiring an affirmative 85 per cent vote for shareholder action. As each shareholder held at least 20 per cent of the stock, the clause in effect required unanimity.

${ }^{88}$ See supra page 464 , especially note 70 .

${ }^{80}$ Sec "reservation" in Sellers v. Joseph Bancroft \& Sons Co., 23 Del. Ch. 13, 26, 2 A. 2d 108, 114 (1938). Compare discussion in Investment Associates v. Standard Power and Light Corp., 29 Del. Ch. 225, 48 A. 2d 501, 506 (1946), $a f^{\prime} d$, 51 A. 2d 572 (Del. Sup. Ct. 1947).

${ }^{90}$ Del. Corp. L. $\$ 5(\mathrm{II})$.

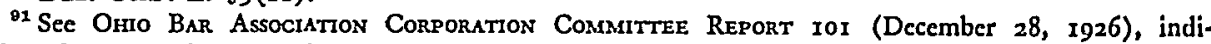
cating that a requirement of a go per cent vote for shareholder action is valid under the Ohio statute, but not mentioning a requirement of unanimity.

${ }^{82}$ See infra page 470. 
that therefore they should not be bound by the unusual control pattern established by those provisions.

The New York stock corporation law ${ }^{93}$ expressly provides that whenever a corporation's certificate of incorporation contains a provision increasing quorum or voting requirements for shareholders' or directors' meetings, "notice of the existence of such provision shall appear plainly on the face or back of every certificate of stock." Although this precise question does not appear to be covered by statute in other jurisdictions, the statutes in most states do contain a number of provisions which taken together may lead the courts to refuse to give effect, at least as against purchasers without notice, to unusual charter or by-law provisions that are not referred to on the certificates of stock. ${ }^{94}$

At any rate, the cautious lawyer will make certain that the veto provisions are referred to on the share certificates. Whenever possible, those provisions should be set forth verbatim on the certificates. If the provisions are too lengthy to be reproduced in full, they should be summarized or paraphrased on the certificates and a clear reference made to the charter or other document containing them.

\section{F. Guarding Against Repeal or Circumvention of Veto Provisions}

After the draftsman has decided what veto provisions to use in the articles and by-laws, he must give careful thought to safeguarding those provisions against repeal, and against circumvention by manipulation of majority interests.

Modern corporation statutes authorize charter amendments by specified shareholder vote; some permit amendment by the vote of holders of a simple majority of the shares with voting power. Similarly, by-laws often can be amended or repealed by a simple majority vote of shareholders or of directors. Thus, veto provisions in the articles or by-laws must be protected against the power of amendment and repeal ordinarily possessed by majority interests. Otherwise, the veto can be thwarted by a two-step process: first, amendment or repeal of the veto provisions; second, passage of a resolution by the shareholders or directors, as the case may be, authorizing the action which before the amendment would have been subject to veto. ${ }^{\text {95 }}$ In most jurisdictions, the remedy is to insert in the charter a clause requiring unanimity or a high vote for amendment or repeal of the charter pro-

${ }^{03}$ N. Y. STK. CoRP. L. $\$ 65$.

${ }^{04}$ Illustrative are the following statutory provisions: PA. Bus. CoRP. L. \$9 (I95I) (no person shall be charged with constructive notice of the articles); PA. Bus. Corp. L. $\$ 305$ (I95I) (by-laws shall not affect dealings with outsiders who do not have actual knowledge of them); Uniform Stock Transfer Act $\$ 15$ (no lien or restriction upon transfer unless indicated on certificate); WIs. Bus. Corp. L. \$180.r8(2) (195I) (share certificates of corporations with more than one class of shares shall state "the designations, preferences, limitations, and relative rights" of the shares of each class). In spite of these statutes, some cases have given effect to restrictions not appearing on the certificates as against transferees with notice. Doss v. Yingling, 95 Ind. App. 494, I72 N. E. 80I (1930); Trefethen v. Amazeen, 93 N. F. IIo, 36 A. 2d 266 (I944); Baumohl v. Goldstein, 95 N. J. Eq. 597, I24 Atl. II8 (Ch. .1924).

${ }^{05}$ See Aldridge v. Franco Wyoming Oil Co., 24 Del. Ch. 126, 7 A. 2d 753 (x939), affd, 24 Del. 349, 14 A. 2d 380 (1940); Warren v. 536 Broad Street Corp., 4 N. J. Super. 584,68 A. 2d 175 (r949), affd, 6 N. J. Super. I70, 70 A. 2d 782 (1950); Markovitz v. Markovitz, 336 Pa. 122, 8 A. 2d 36 (1939). But see Bechtold v. Coleman Realty Co., 367 Pa. 208, 79 A. 2d 66I (195x). 
visions establishing a veto; and to insert in the charter, in the by-laws, or in both instruments, ${ }^{96}$ clauses requiring a unanimous or high vote for the modification or repeal of veto provisions in the by-laws. ${ }^{97}$

Most corporation statutes permit unanimity or a high percentage vote to be required for amendments of charter or by-laws. ${ }^{.8}$ In a few jurisdictions, however, doubt exists whether a clause which sets the vote for charter or by-law amendments higher than the figure fixed by statute would be sustained; some statutory provisions specifying the vote for charter or by-law amendments are couched in language that can be interpreted as mandatory.99 In those jurisdictions, perhaps veto provisions in the charter and by-laws can be protected against amendment by an agreement between the company and its shareholders not to amend. ${ }^{\mathbf{1 0 0}}$

A power of veto may also be lost through merger or consolidation; or shareholders attempting to exercise a veto may be "frozen out" by the dissolution of the corporation and the formation of a new corporation without the dissenters or by the transfer of all corporate assets to another enterprise. ${ }^{101}$ Therefore, approval of all or of a high perecentage of shareholders should normally be required for such fundamental corporate acts as a merger, consolidation, dissolution or the transfer of all corporate assets.

Veto provisions based on a high percentage vote of shareholders must be protected from circumvention through the issuance of additional shares. Otherwise, majority interest may be able to deprive a minority shareholder of his power to veto simply by increasing the number of outstanding shares until his holdings are less than the fraction of outstanding shares required for a veto. Frustration of the veto by that procedure can usually be avoided by the insertion of appropriate provisions in the charter, e.g., clauses providing that treasury shares and authorized but unissued stock can be issued only with the approval of holders of a specified pro-

\footnotetext{
${ }^{00}$ Provisions governing the amendment of by-laws often may be placed in either the charter or by-laws. Whenever the law permits, the provisions should be inserted in both. See supra page 465 .

${ }^{97}$ Of course special provisions of this kind are not necessary if an effective veto has been given over all amendments of charter and by-laws. In most states, unanimity or a high vore apparently can be required for amendment of some charter and by-law provisions and a lesser vote for amendment of other provisions.

${ }^{88}$ See e.g., DeI. Rev. Code c. 65, 22037 (II) (1935); N. Y. StK. CoRp. L. \$37; PA. Bus. Corp. L. $\$ \$ 304,805$ (I95I); UNIF. Bus. CoRP. ACT \$38 (II, III). Even Benintendi v. Kenton Hotel, 294 N. Y. III2, 60 N. E. 2d 829 (1945), which declared invalid a number of veto provisions in the by-laws, sustained a by-law requirement of unanimous approval of the sharebolders for amendment to the by-laws. But see "reservation" in Sellers v. Joseph Bancroft \& Sons Co., 23 Del. Ch. 13, 26, 2 A. $2 d$ 108, 114 (Ch. 1938), indicating that in Delaware a requirement of a hundred per cent vote for charter amendment may be invalid.

${ }^{80}$ See strong dictum in Warren v. 536 Broad Street Corp., 4 N. J. Super. 584,68 A. 2d 175, 180 (1949), aff d, 6 N. J. Super. I7o, 70 A. $2 d 782$ (1950), that the two-thirds vote specified in New Jersey amendment procedure is mandatory.

${ }^{100}$ In British Murac Syndicate, Ltd. v. Alperton Rubber Co., Ltd., [1915] 2 Ch. I86, a company was restrained from violating a contract not to alter its articles of association, the contract having been entered into by the company and a syndicate holding some of its stock. But see views expressed in Aldridge v. Franco Wyoming Oil Co., 24 Del. Ch. 126, 7 A. 2d 753 (r939), aff'd 24 Del. 349, 14 A. 2d 380 ( 1940$)$, on alleged oral agreement by shareholders not to amend charter.

101 See Kavanaugh v. Kavanaugh Knitting Co., 226 N. Y. 185, 123 N. E. 148 (1919).
} 
portion of the shares outstanding, clauses requiring a unanimous or high shareholder vote to increase the amount of authorized stock, clauses assuring shareholders a preemptive right in new issues of shares, ${ }^{102}$ and combinations of these.

Similarly, veto provisions requiring a high percentage vote for action by the directors may be nullified by an increase in the number of directors. ${ }^{103}$ The risk can usually be avoided by fixing the number of directors in the charter or by-laws, and requiring a high shareholder vote to increase the size of the board. ${ }^{104} \mathrm{~A}$ shareholder with a veto must also be protected against the possibility of losing his veto over matters within the province of the directors through the death or incapacity of the director representing his interests. The desired result can usually be achieved by stating in the charter or by-laws that the board cannot act until a vacancy has been filled, and requiring unanimous shareholder approval to fill the vacancy. In some situations, it may be possible to give the shareholder power to fill a vacancy created by the death of his representative on the board.

Finally, thought must be given to the possibility that corporate officers and agents may act beyond their authority and bind the corporation to outsiders. ${ }^{105}$ The safeguard against that danger is to appoint reliable officials and require them to furnish adequate bonds. ${ }^{106}$

\section{VIII}

\section{Conclusion}

Lawyers have too seldom taken advantage of the flexibility permitted by modern corporation statutes to mold the corporate device to the needs of closely held enterprises and to the desires expressed by the participants in their business bargains. Those needs and desires can frequently be met by the use of the special charter and by-law provisions discussed in this paper.

Although these veto provisions are exceedingly useful tools in fashioning management patterns for closely held corporations, the limitations and disadvantages of veto provisions must not be overlooked. In the first place, they give a veto and no

\footnotetext{
${ }^{102}$ Preemptive rights alone are not a complete protection to a shareholder of limited means, because at the critical time he may not have funds available to exercise his pre-emptive rights.

${ }^{103}$ The danger that a veto arrangement may be circumvented by an increase in the number of directors is illustrated by Odman v. Oleson, 319 Mass. 24, 64 N. E. $2 d 439$ (1946). See also Christal v. Petry, 275 App. Div. 550, 90 N. Y. S. $2 d 620$ (Ist Dep't I949), aff'd mem., 30r N. Y. 562, 93 N. E. 2d 450 ( 1950 ), holding that the by-laws may not restrict the statutory right of majority shareholders to increase the number of directors, but indicating that a restriction of that kind would be effective if inserted in the certificate of incorporation or if unanimously approved in writing by the shareholders.

104 But see Christal v. Petry, 275 App. Div. 550, 90 N. Y. S. 2d 620 (Ist Dep't r949), aff'd mem., 3or N. Y. 562, 93 N. E. 2d 450 (1950), holding that by-law provision requiring approval of 75 per cent of the voting stock to increase the number of directors was void as inconsistent with a statute providing that the number of directors may be increased by the holders of a majority of the outstanding shares.

${ }^{105}$ In most states, limitations on the authority of corporate officers contained in charter and by-law provisions will not bind outsiders who do not have actual notice. See, e.g., PA. Bus. CoRP. L. \$\$9, 305 (195I).

${ }^{100}$ See Ballard, Arrangements for Participation in Corporate Management Under the Pennsylvania Business Corporation Law, 25 TEMP. L. Q. 13I, I54-5 (195I).
} 
more; they do not enable minority shareholders to determine policy affirmatively and to go forward with the execution of that policy. Secondly, they deprive the corporation of flexibility which it may need to adjust to unexpected business situations. At the time an enterprise is being incorporated, the draftsman cannot foresee changes in policy and methods of operation which may in the future become advantageous. Finally, veto provisions may place one or two shareholders in a position to extort (as a condition of approval of beneficial corporate action) unfair concessions from the other shareholders. The use of veto provisions therefore involves a problem of balancing the safeguards necessary to protect the interests of minority shareholders against the freedom of action that is beneficial to the corporation and the shareholders as a group. 